\section{United Nations peacekeeping: limitations and prospects}

Nadège Sheehan

$\mathrm{O}$ 29 May 2008, the United Nations celebrated the 60th anniversary of U.N. peacekeeping operations. Between 1948 and 2008, sixty-three peacekeeping operations have been deployed. As of the end of April 2008, 107,670 personnel were serving in 17 peacekeeping operations. The current peacekeeping budget is estimated at $\$ 6.8$ billion, representing only about half of one percent of global defense spending. ${ }^{1}$ U.N. peacekeeping is definitely a cost-effective solution to deal with war-torn societies, ${ }^{2}$ so why is the provision of U.N. peacekeeping operations so problematic? Why can nations not give their full financial support to U.N. peacekeeping? The answer is that peacekeeping is a regional or even global public good and, like all public goods, it entails the underlying problems of free-riding and disproportionate burden-sharing. It is always more desirable to let others pay for a good that one can enjoy at no cost or with minimal investment.

It is difficult to find solutions that would make nations eager to give their contributions to create peace, regardless of their own benefits. As the problem of freeriding is less severe when peacekeeping provides contributor-specific benefits, ${ }^{3}$ why not implement a system that would motivate the production of peace by those nations with particular interests in a conflict? If nations can be given the opportunity to focus their efforts in areas that are more cost-beneficial for them, U.N. peacekeeping could likely be more efficiently produced. Conflicts resolution could be more effective because the funds and staffing would be more readily available.

This essay discusses some reasons why it is so difficult to efficiently produce U.N. peacekeeping and presents potential production systems that could better produce peace.

United Nations peacekeeping is a public good that not all nations may benefit from

A public good is nonexcludable and nonrivalrous. There is no exclusion from consumption by price. Once the good is made available to one, it becomes available to all and one cannot decide whether to consume the good. Because they produce peace, U.N. peacekeeping operations are considered public goods. Inasmuch as they reestablish trade and international relations, they also generate private and semi-private goods (for the nation). And although the international community benefits from this, the foremost beneficiary is the country where the deployment takes place. But the production of peace may not reach all groups equally in a nation.
Situations of displaced persons generate instability in a nation and can prevent others from enjoying peace. Despite free and democratic elections in the Central African Republic in 2005, for example, the country cannot reap the benefits of peace because of the insecurity caused by the large number of

displaced persons. As of April 2008, the Internal Displacement Monitoring Center counts 101,000 displaced persons on the borders with the Sudan and Chad. Some South Africans cannot enjoy peace because of the large number of displaced Mozambicans in South Africa. South Africans blame Mozambicans for crime and unemployment. ${ }^{4}$ Some groups may not be able to enjoy peace because there are too many firearms left after an incomplete disarmament process. These groups may have to invest in measures to ensure their own safety; those who cannot afford to pay for additional security will continue to feel unsafe. Consumption of peace can therefore be excludable by price.

If all U.N. members accepted to participate in the financing of a particular operation, this still would not guarantee that a mission can be deployed. A nation in conflict can refuse deployment of U.N. peacekeepers on sovereignty grounds, for example because it does not value peace or because the country considers that the potential deployment is unduly influenced by a big power with whose objectives the target country disagrees. Fearing that the United States was aiming at regime change, the Sudanese government long resisted the deployment of non-African forces to help manage the crisis in Darfur. ${ }^{5}$ Only in cases of genocide and mass killings can the United Nations compel deployment, using the Responsibility to Protect principle. ${ }^{6}$ Otherwise, the conflict death toll continues to increase, while diplomatic efforts are carried out. We thus face a situation where a public good (peacekeeping) cannot be produced because the main beneficiary (the nation in conflict) refuses to consume the good.

U.N. peacekeeping can be costly if its products, including peace, are to be enjoyed. It is also expensive to force someone or a nation to consume its benefits. It is the type of good that cannot be well produced by the market, even though there are contributor-specific benefits.

The production of peacekeeping by a single nation, whatever its wealth, is unrealistic. Besides, no government would accept to support the entire cost of a mission that would be more cost-beneficial to other nations; and it would be difficult to implement a national peacekeeping financing system that would solely depend on voluntary contributions, except in the case of hegemony where the hegemonic country would find indirect ways to get the missions paid for. As compared to the United Nations budgeted amount of $\$ 428$ million, a study prepared by the U.S. Government 
Accountability Office estimated that it would cost the United States approximately $\$ 876$ million to conduct a peacekeeping operation similar to the United Nations Stabilization Mission in Haïti (MINUSTAH) for the first 14 months of the mission. ${ }^{7}$ There is also a limit to the volume of resources that can be mobilized, and in the activities that can be carried out by any one nation. The government/producer will then have to demand financial participation from other nations in order to finance peacekeeping expenditures. However, suppose that the participation level required from each nation seems equitable, what authority would be able to enforce payment? Unless forced (by some kind of tax), governments are not disposed to contribute to the production of a good, or unless motivated to do so by some prospect of direct gains.

The United Nations' scale of assessment does not facilitate efficiency in the production of peacekeeping operations

With some adjustments, U.N. peacekeeping is based on the scale of assessment for the regular U.N. budget. Expenses are apportioned according to capacity to pay. Two criteria considered most relevant by the U.N. Committee on Contributions are used to define this capacity: first, average per capita gross national income (GNI) and, second, conversation rates based on market exchange rates in U.S. dollars, except in cases where that would cause excessive fluctuations and distortions in the income of some countries. To bring equity to the scale, a system of discounts representing debt-burden adjustment, is added. Broadly speaking, annual GNI figures in national currency are converted to U.S. dollars using the annual conversion rate. The average of these figures is calculated for a base period of three or six years. The average GNI figures are then summed up and used to calculate shares of GNI. A debt-burden adjustment is then applied. It represents an average of 12.5 percent of total external debt for each year of the period. The amount of the debt-burden adjustment is then deducted from the GNI of countries with a per capita income of up to $\$ 10,725$. $^{8}$

The peacekeeping scale of assessments is subject to a complex calculation that still does not guarantee equity and does not reach the objective of maximizing contributions to peacekeeping operations. The U.N. peacekeeping scale of assessments represents a tax, based on the ability to pay principle. But, unlike taxes controlled by a national government, there is no authority and no international law to punish nations that do not pay their assessment to peacekeeping. The only punishment that the United Nations can use is not to allow members to exercise their right to vote in the U.N. General Assembly (Article 19). Countries that want to protect that right can present economic reasons as to why they cannot fulfill their payment obligation and can propose a multi-year payment plan. However, if the United Nations approves the plan, payments owed to U.N. peacekeeping are converted into debt, deepening developing countries' financial burden. Nevertheless, a nation's debt to peacekeeping may become part of the nation's public debts and then taken into account in the debt-burden calculations for the assessments. As it is likely that the needs for peacekeeping operations and the costs involved will continue to go up, the debt that a few developing nations have in U.N. peacekeeping will increase, making them less likely to fulfill their future financial obligations. For instance, average assessments to be paid by Liberia between 2000 and 2007 were $\$ 22,278$. In December 2004, the country had an outstanding debt of $\$ 1,169,567$. In 2005 , Liberia had its regular assessment of $\$ 24,264$ added to its debt. However, Liberia only paid $\$ 202$. This means that Liberia did not pay its assessment and increased its outstanding balance to $\$ 1,193,629$. Under the burden of past debts and new assessments due, some countries, like Sao Tome and Principe, just stop making payments. ${ }^{9}$ Although the United Nations finds that payment plans have had a consistently positive impact in reducing arrears, financing of U.N. peacekeeping remains problematic. As the budget for the upcoming year is established for actual peacekeeping needs, when nations cannot or do not pay their share of assessment, there is a shortage of funds for financing the missions.

As currently structured, the peacekeeping scale of assessment leads countries to play games with the classification system. Nations can request to move to a higher or lower assessment category (if they meet the requirements). Just like people, nations generally will not propose to pay more unless there are some economic or political interests that motivate them to do so, such as their world image. A country that chooses to move up the scale may well be concerned that it will suffer a relative loss of wealth, political weight, and influence on global security if it is placed at a lower per capita level of assessment. However, the fact that a country can voluntarily choose to move up in the assessment scale shows that the United Nations most likely miscalculated its capacity to pay to begin with. As calculation periods for future assessments are made based on economic data for an average of the past 5 years (e.g., effective rates of assessment for the January 2007 to December 2009 peacekeeping budget were based on GNI calculated for the period 1999 to 2004), a country's economic situation can change significantly, especially in the presence of exchange rates fluctuations.

The discount system, adjusted for equity, could have psychological effects on the contribution behavior of the five permanent members of the U.N. Security Council, making it more difficult for the United Nations to reach the level of financing needed to produce planned peacekeeping operations. Even though the surcharge imposed on these countries may be relatively insignificant, these members could feel that they are heavily taxed and their motivation to contribute may be reduced. The largest financial contributors today are the European Union, Japan, and the United States. ${ }^{10}$

Production of United Nations peacekeeping by national armies: a costly system

In the absence of a permanent force, the United Nations must rely on the quantities and qualities of military personnel, equipment, and supplies that countries desire to 
contribute to each mission. Undoubtedly, this is inadequate for producing effective peacekeeping operations. The production of peacekeeping by a patchwork of national armies raises issues of heterogeneity in troops, and subsequent negative externality costs. Each contributing nation has its own training system, its own culture, language, and customs. The training level and communication skills of the soldiers are often significantly different. These differences create costs of coordination and efficiency; they can create negative externalities, generating internalization costs.

As contributions of military personnel and equipment are left to the discretion of nations, more developing countries send personnel military to U.N. peacekeeping operations. To participate in a mission, the gains nations plan on obtaining have to be higher than the costs. Deployments of U.S. troops to Haïti, both in 1994 and in 2004 were based on national interests. Severe instability in Haïti led to increasing numbers of Haïtians to take refuge in the United States. Perito notes that 1994 was the first time that the United States provided a contingent for both a coalition and a U.N. police force. ${ }^{11}$ In 2004, the United States led a U.S. Multinational Interim Force to create stability in Haïti. Among other costs, rich countries consider injury and death risks for their soldiers and the likely reduction of their national security caused by thinning of national forces. The danger involved in peacekeeping operations, particularly as peacekeepers from developed nations have to fight alongside those of developing nations, has led rich countries to favor contributions of equipment and supplies over human contributions. The value of life of peacekeepers enters into the participation decisionmaking process. Seiglie notes that, ceteris paribus, a person with greater earnings or life expectancy has a higher value of life. ${ }^{12}$ The presence of large populations, and particularly of potential economic gains, are also important factors in the participation decisionmaking process.

Developing countries have large numbers of soldiers already serving in local armies. They also have substantial numbers of unemployed young men. By contributing troops, not only can poor nations potentially reduce crime and unemployment rates, but can find occupations for excess soldiers. Developing countries are also eager to supply troops to U.N. peacekeeping because of the benefits they gain from reimbursements, ordinarily far higher than their expenditure in training soldiers. The United Nations reimburses troop-contributing nations at a monthly rate of about $\$ 1,000$ per soldier, on top of direct payments to military personnel of $\$ 1.28$ per day per contingent member and a leave allowance of $\$ 10.50$ per day for up to seven days. Using Haïti as a case study, Solomon finds that 70 percent of U.N. expenditures of $\$ 134$ million were reimbursement costs to troop-contributing countries. ${ }^{13}$ Estimated data for 2003 of troop costs of five top contributors versus U.N. reimbursements made to them show the kind of profit developing nations can make. After taking into account assessments paid by these nations, data show that Bangladesh, Ghana, India, Jordan, and Pakistan made profits that amounted, respectively, to $\$ 31.3, \$ 10.5, \$ 15.5, \$ 0.03$, and $\$ 3.4$ million. Taking Canada as an example, Solomon notes that, in 2003, its assessment amounted to $\$ 78$ million, a sum higher than the combined estimated troop costs for the five countries (\$72.9 million). The estimated U.N. reimbursement to Canada was about $\$ 2.4$ million, for an estimated number of 200 personnel. ${ }^{14}$

Developing nations also benefit from the training given to their military personnel engaged in U.N. missions. The armies return to their country better trained and can contribute, presumable, more efficiently to national security. Furthermore, the training provided by the United Nations reduces the training costs that these developing nations otherwise would have had to take up (in countries where training is taken seriously). In participating in U.N. peacekeeping activities, there are, then, substantial benefits to be gained by soldiers from poor countries and by their government as well.

Unpaid assessments lead to debt: fewer funds are available to produce peacekeeping operations

When nations do not pay their assessments, it becomes difficult for the United Nations to reimburse contributing nations and suppliers of goods and services, and to finance peacekeeping support staff. The United Nations estimated that, as of 30 April 2008, outstanding contributions to peacekeeping amounted to $\$ 2.3$ billion. When the United Nations cannot reimburse countries for their participation in U.N. missions, these nations are less eager to contribute to future missions. Developing countries are those that generally contribute the largest number of military personnel; however, they also have the lowest assessment rates. The financial contributions made by rich nations are those that allow the United Nations to reimburse developing countries. But as contributions depend on the levels of national interests, the timing of payments, and their amounts, will fluctuate.

The lack of financial resources also prevents the United Nations from paying its bills to suppliers of goods and services. Subsequently, the organization must reduce its purchases and cannot benefit from economies of scale. Furthermore, the materials purchased can be inadequate and of poor quality. This affects the efficiency of peacekeeping operations. For example, during the U.N. Transitional Authority Mission in Cambodia (UNTAC), the locks on election ballot boxes were not strong and broke. This situation led the Cambodian departing government to qualify the election as fraudulent and to threaten the secession of eastern provinces. ${ }^{15}$

The inability to finance adequate support staff can also affect the missions and create costs. In 1994, the United Nations was not able to hire an adequate number of translators to help form a police force in Haïti, and it had to limit travel frequencies, 
staff overtime, and meeting sessions. Slow deployments make the missions less credible, as happened with UNTAC. The Khmers Rouges did not to release their weapons because they had noticed that the United Nations was not in control of the situation. ${ }^{16}$

The efficiency of United Nations peacebuilding efforts is questioned

Some scholars believe that some U.N. peacekeeping operations undertake tasks beyond their abilities. ${ }^{17}$ They feel that the United Nations does not have the resources to answer the high demands faced in civil war. Soldiers are not sufficiently armed to face situations of anarchy in Angola, Bosnia, Croatia, Haïti, Liberia, Rwanda, or Sierra Leone. The peace reached in Cambodia was not sustainable. As soon as U.N. peacekeepers left, local conflict and despotism erupted. Fleitz indicates that the problems of despotism and kleptomania in Angolia, Cambodia, Haïti, and Liberia were due to corrupt elections supervised by the United Nations. He believes that the civil war in the Democratic Republic of Congo was the consequence of a bad peace agreement and that, for Angola, Liberia, Rwanda, and Sierra Leone, bad peace agreements worsened the refugee problems. He adds that in his view the genocides in Bosnia and Rwanda also are due to the failures of peacekeeping operations and the flawed implementation of democratic institutions in nations at war.

For others, peacebuilding efforts generate corruption, criminality, poverty, and inequality. ${ }^{18}$ Peacekeeping often introduces economic policies that do not improve the situation of the people that are most vulnerable. The neoliberal model of political economy cannot be applied to nations at war while seeking to carry out peacebuilding efforts, because these kinds of societies suffer from multiple governmental, political, social, and economic pressures and failures. According to Tardy, diseconomies generated by U.N. peacebuilding efforts can be attributed to the tendency that these activities have to benefit certain social groups. In Mozambique, for instance, the rebuilding of the economy mainly benefitted urban companies and people who had access to the comparatively modern sector of the South. ${ }^{19}$ Pugh and Cooper believe that the fight against corruption destroys an important revenue source for poor people. Subsequently, new forms of criminality appear. Only 10 percent of Angola's GNP is said to come from legal commerce. About 80 percent of the Afghan economy is financed by illegal activities, and between 30 and 50 percent of the population have been involved in drug trafficking. For Johnstone and Corbin, peacekeeping cannot succeed unless it is accompanied by a viable political process. ${ }^{20}$ The main parties in the conflict must remain politically engaged. Furthermore, it is important that this political process be inclusive and that it encompasses community leaders, civil society representatives, and other important actors. When the North-South war in Sudan ended, there was concern that war could re-erupt before the planned referendum on southern independence in 2011 , because the parties had ceased to be engaged politically.
Getting around the free-riding problem to produce peacekeeping operations

As problematic as the production of U.N. peacekeeping is, and although some authors may have doubt about the efficiency of the missions, peace has to be produced. It is unreasonable to envisage dealing with the full magnitude of conflicts without U.N. peacekeeping. The public good characteristics of U.N. peacekeeping make it impossible to compel nations to contribute fairly to peacekeeping. There are even fewer chances that those nations that do contribute will feel the same urge to participate in every mission. We should therefore explore potential alternatives that enhance the efficient production of peacekeeping, regardless of free-riding issues.

Seiglie proposes a system of marketable or tradable obligations. ${ }^{21}$ All member nations would be required to provide a given number of troops to an operation based on its population, or the size of their economy, or some other criteria. He explains that if the United States is obligated to contribute 26 percent of troops to a mission, it can do so either by supplying its own force to the mission or by purchasing the tradable obligations of other nations. The United Nations would provide the institutional structure for the market, establish the rules, and regulate the behavior of the participants. Seiglie indicates that this system can only work if there is no conscription; otherwise, there is a situation of potential exploitation of conscripts. Although Seiglie's proposal is a form of privatization of peacekeeping, with a force not unlike mercenaries, it shows a potential for producing peacekeeping. Countries would have to be careful not to purchase the tradable obligations from nations that do not have sufficiently trained soldiers. Seiglie's proposal would have to be packaged with peacekeeping training programs for developing nations. For instance, the United States implemented programs to develop the capacity of coalition institutions, such as African Union and the Economic Community of West African States, to carry out peacebuilding efforts. ${ }^{22}$

Solomon considers the possibility of contracting-out U.N. missions to a single country, one at a time. ${ }^{23}$ He believes that this would reduce the set-up costs of a multinational force. Countries could be motivated to propose to carry out a mission if their middle-power status is enhanced by the operation. He notes that the contracted nation would need to be well-experienced in carrying out a peacekeeping operation. It may seize the opportunity to dictate the postconflict environment in the region. But it may not be accepted in the country in conflict. For example, a country may not trust an African Union-led mission if it contains soldiers of the same ethnic group than of the adversarial fighting group. Solomon's proposal suffers from at least one limitation: it suggests that one nation, alone, could produce a peace operation. As stated earlier, this is not plausible because a single nation cannot, by itself, carry out all of the tasks needed to produce peacekeeping efficiently. Solomon's proposal could work if the role of the contracted nation is to be the leader in drawing up the various tasks to be carried out (the nation would, in effect, be a prime contractor), in generating cooperation among the various actors involved in the mission, and in 
implementing institutions that would intervene to produce peace. It would have to work in concert with international organizations. For this, the contracted nation would need to have powerful multinational status already. This proposal could potentially work well if we see the contracted nation as the leading country in a region, such as South Africa in Africa. The United States would certainly be a candidate nation to contract, as it has the capacity to bolster the capacity of established operations and to reinforce the contribution of other nations to peacekeeping. ${ }^{24}$ It has been a key partner in many peacekeeping arrangements already, such as the hybrid Africa Union/United Nations mission. But the United States would probably not accept a contract, as this would mean that it is working for others. Furthermore, its geographical regions of interests are limited.

Fetterly sees the answer to the suboptimality problem in the use of demand-based funding for peacekeeping operations. ${ }^{25}$ Countries with specific national interests could put money into a U.N. Trust Fund to be used for particular missions in a region, and thereby alleviate other nations from the burden. He indicates that as Europeans and North American nations would concentrate their efforts and allocate their financial resources to provide peace in their own regions, this would allow the United Nations to use the peacekeeping budget to deploy missions elsewhere (especially in Africa, Asia, and the Middle East). These nations do not have the resources to help finance a Trust Fund. In 2007, the U.N. Secretary General established a Trust Fund to back diplomatic efforts to end the conflict in Darfur. ${ }^{26}$ Among its other donations to help Darfur, Japan, for instance, provided the United Nations with amounts totaling $\$ 0.78$ million between January 2005 and July 2007 for a Trust Fund for assistance in antimine action. ${ }^{27}$ In this regard, the U.N. Secretary General recently suggested exploring the implementation of a possible common start-up fund to finance peacekeeping operations. ${ }^{28}$

Regional coalitions are also a possible solution for producing peace, getting around free-riding behavior. A study by Brauer and Roux shows that an alliance can be based on free-riding and yet work. ${ }^{29}$ In the Southern African Development Community (SADC), South Africa is the most powerful member because of its significant economic size within the region. There is no doubt that South Africa's economic gains are higher than its contribution to the group. Without South Africa's membership, SADC would not have the resources to be successful in bringing peace to the region. Thus, the free-rider issue may not prevent the production of a public good if all members, including the one supporting the financial burden, benefit from their membership.

\section{Conclusion}

After six decades of peacekeeping, it is evident that it is difficult to equitably produce peacekeeping. None of the 192 U.N. member states can be forced to participate in the production of a peace mission. Using contributor-specific benefits, we must implement other proposals for producing peace, regardless of free-riding behavior. Among these proposals are ideas of marketable or tradable obligations, a U.N. Trust Fund for peacekeeping, regional coalitions, a start-up fund, and to a lesser extent, contracting a single nation to produce peacekeeping. Whichever system is used, it is unlikely to work without the full involvement of the United Nations. The United States is militarily powerful, indeed, but its success rate measured by its ability to produce lasting peace is lower than that of the United Nations ${ }^{30}$ Since Iraq, the United States understands that its efforts of nation-building are best achieved when they take place through a truly multilateral framework. ${ }^{31}$ To effectively carry out peacebuilding activities, it is crucial that the United Nations work closely with local governments to establish the institutions that will be necessary to maintain peace. According to Dobbins, efficient peacekeeping today calls for a more professional approach to peacebuilding. Nation-building encompasses efforts of security, humanitarian relief, governance, economic stabilization, democratization, and development. Using this approach, countries like Canada, Germany, the United Kingdom, and the United States have set up offices to manage their countries' participation in postconflict stabilization and reconstruction. ${ }^{32}$ A Peacebuilding Commission was implemented by the United Nations to coordinate the efforts of the various actors involved in peacebuilding efforts. The United Nations is a credible and experienced body, and the magnitude of nation-building activities that postconflict situations call for cannot be done without the United Nations.

Notes

Nadège Sheehan obtained a Ph.D in Economics from the University Pierre Mendès France of Grenoble, France. She concentrates her research on the economics of international security and defense. A scientific member of the "Centre des recherches économiques sur la politique publique en économie de marché (CREPPEM)" in Grenoble, France, she may be reached at nadege.sheehan@verizon.net.

1. See GP [(n/d (b)]. Also see SIPRI Yearbook 2008 for world military spending.

2. See, e.g., "The Canadian Contribution to United Nations Peacekeeping." United Nations Association in Canada. www.unac.org/peacekeeping/e/pdf/CdnUNPkpg Booklet_e.pdf; B.D. Shaeffer. 2007. "Time for a New United Nations Peacekeeping Organization.” Background \# 2006, The Heritage Foundation - Leadership for America, February 13, 2007: www.heritage.org/Research/InterntionalOrganizations/ bg2006.cfm.

3. See Shimizu (2005).

4. IDCM (2007); NYT (2008). 
(C) www.epsjournal.org.uk - Vol. 3, No. 2 (2008)

\section{Johnstone and Corbin (2008).}

6. See R2P (n/d).

7. See UN (2008a).

8. UN (2007a).

9. UN (2007a).

10. UN (2008c).

11. Perito (2008).

12. Seiglie (2005); also see Yakovlev (this issue).

13. Solomon (1999).

14. Solomon (2007).

15. Ledgerwood (1994).

16. Haïti: (Holt, 1996); Cambodia: Ledgerwood (1994).

\section{Debiel (2000); Fleitz (2002).}

18. For instance, David (1998), and Pugh and Cooper (2004).

19. Tardy (2000).

20. Johnstone and Corbin (2008).

21. Seiglie (2005).

22. Bah and Aning (2008).

23. Solomon (1998, 1999).

24. Johnstone and Corbin (2008).

25. Fetterly (2006).

\section{UN (2007b)}

27. EJS (2008).

28. UN (2008c)

29. Brauer and Roux (2000).

30. Dobbins (2008)

31. Johnstone and Corbin (2008).

32. Dobbins (2008).

\section{References}

Bah, A. S. and K Aning. 2008. "U.S. Peace Operations Policy in Africa: From ACRI to AFRICOM." International Peacekeeping, Vol. 15, No. 1, pp. 118-132.

Brauer, J. and A. Roux. 2000. "Peace as an International Public Good: An Application to Southern Africa." Defence and Peace Economics, Vol. 11, pp. 643-659.

Brauer, J. and A. Roux. 1999. "La paix comme bien public international: Une application préliminaire à Afrique Australe." Pax Economica-Revue Economique de la Paix, Vol. 2, No. 2

[CLW] Council for a Liveable World. "The United Nations Financial Crunch: The U.S. Role in Creating the Crisis, Project on Peacekeeping and the United Nations." A Project of Council Livable World Education Fund, http://www.clw.or/pub/clw/un/uncrisis.html.

David, C.-P. 1998. "Les limites du concept de consolidation de la paix." Revue internationale et stratégique, No. 31, automne, pp. 57-75.

Debiel, T. 2000. "Strengthening the U.N. as an Effective World Authority: Cooperative Security Versus Hegemonic Crisis Management." Global Governance, No. 6, p. 33.

Dobins, J.F. 2008. "Towards a More Professional Approach to Nation-Building." International Peacekeeping, Vol. 15, No. 1, pp. 67-83.

[EJS] Embassy of Japan in Sudan. 2008. “Japan's Assistance to Sudan since 2005.” Embassy of Japan in Sudan. http://www.mofa.go.jp/policy/oda/region/africa.

Fetterly, R. 2006. "A Review of Peacekeeping Financing Methods." Defense and Peace Economics, Vol. 17, No. 5, pp. 395-411.

Fleitz, F.H. Jr. 2002. Peacekeeping Fiascoes of the 1990s: Causes, Solutions, and U.S. Interests. Westport, CT: Praeger.

[GP] Global Policy. n/d (a). Globalpolicy, http://www.globalpolicy.org/finance/ tables/pko/undues00.htm. 
[GP] Global Policy. n/d (b). Globalsecurity.org, http://wwwglobalsecurity.org/ military/world/spending.htm.

Holt, V.K. 1996. "Reforming U.N. Peacekeeping: The U.S. Role and the Financial Crisis." The Brown Journal of World Affairs, Vol. III, No. 1, p. 127.

[IDMC] Internal Displacement Monitoring Centre. 2007. "International Displacement in Central African Republic: A Protection Crisis.” 26 January 2007. Internal Displacement Monitoring Centre (IDMC). http://www.internal-displacement.org.

Johnstone, I. and E. Corbin. 2008. "The U.S. Role in Contemporary Peace Operations: A Double-Edged Sword.” International Peacekeeping, Vol. 15, No. 1, pp. 1-17.

Ledgerwood, J.L. 1994. "U.N. Peacekeeping Mission: The Lessons from Cambodia." Analysis from the East-West Center, No. 11, March.

[NYT] The New York Times. 2008. "Mozambique Fears 'Exodus' From Violence in South Africa.” 24 May 2008. http://www.nytimes.com/2008/05/24/world/Africa.

Perito, R.M. 2008. "Police in Peace and Stability Operations: Evolving U.S. Policy and Practice." International Peacekeeping, Vol. 15, No. 1, pp. 51-66.

Pugh, M. and N. Cooper. 2004. War Economies in a Regional Context: Challenges of Transformation. Boulder, CO: Lynne Rienner Publishers.

[R2P] Principle of "Responsibility to Protect." n/d. http://www.r2pcoalition.org.

Shimizu, H. 2005. "An Economic Analysis of the U.N. Peacekeeping Assessment System.” Defence and Peace Economics, Vol. 16, No. 1, pp. 1-18.

Solomon, B. 1998. "The Economic Consequences of a Peacekeeping Mission on the Host Country: Haiti," pp. 166-182 in A. Woodcock and D. David, eds. Cornwallis III: Analysis of Peace Operations. Cornwallis: Canadian Peacekeeping Press.

Solomon, B. 1999. "Economic Analysis for a Peacekeeping Mission." Peace Economics, Peace Science, and Public Policy, Vol. 5, Article 2. http://www.bepress.com/peps.

Solomon, B. 2007. "Political Economy of Peacekeeping," pp. 742-774 in T. Sandler and K. Hartley, eds. Handbook of Defense Economics, vol. 2. Amsterdam: Elsevier.

Seiglie, C. 2005. "Efficient Peacekeeping for a New World Order." Peace Economics, Peace Science, and Public Policy, Vol. 11, Article 2. http://www.bepress.com/peps.

Tardy, T. 2000. "Le bilan de dix années d'opérations de maintien de la paix." Politique Etrangère, No. 2, p. 401.

[UN] United Nations. n/d (a). United Nations Peacekeeping: Meeting new Challenges, FAQ. http://www.un.org/Depts/dpko/dpko/faq/.

[UN] United Nations. n/d (b). Repertory of Practice of United Nations Organs, Article 19. http://untreaty.un.org/cod/repertory/art19/english/rep_supp6_vol2-art19_e.pdf.

[UN] United Nations. n/d (c). Honouring 60 years of United Nations Peacekeeping, FactSheet. http://www.un.org/events/peacekeeping60/factsheet.shtml.

[UN] United Nations. 2000. General Assembly Document no. A/54/859. "Review of the rates of reimbursement of the Governments of troop-contributing States." 5 May 2000. http://www.un.org/ga/acabq/reports.

[UN] United Nations. 2007a. General Assembly Document no. A/62/11. Report of the Committee on Contributions, 11-29 June 2007.

[UN] United Nations. 2007b. Ban Ki-moon Unveils Trust Fund to Back Diplomatic Efforts to End Darfur Conflict, UN News Centre online, 21 September 2007.

[UN] United Nations. 2008a. United Nations Department of Public Information, United Peacekeeping Operations, Background Note, 30 April 2008. http://www.un.org/Depts/dpko/dpko/bnote.htm.

[UN] United Nations. 2008b. Secretary-General outlines path for peacebuilding in Security Council debate, UN News Centre, 20 May 2008.

[UN] United Nations. 2008c. Department of Public Information, Press Release $\mathrm{PKO} / 181,27$ May 2008. 